Rie Popp Troelsen er ansat som adjunkt ved Forskningsenhed for Matematikkens og Naturfagenes Didaktik på Danmarks Pædagogiske Universitet. Her arbejder hun hovedsageligt med et projekt om unges interesse for naturfag, men beskæftiger sig også med universitetspædagogik inden for naturvidenskab og teknik. Rie har en ph.d. i naturvidenskabsdidaktik fra 2003 og har tidligere arbejdet med adjunktuddannelsen på de naturvidenskabelige og tekniske fakulteter som pædagogisk projekt og været med i arbejdet omkring den danske strategiplan: Fremtidens Naturfaglige Uddannelser.

\title{
Interesse og interesse for naturfag
}

\begin{abstract}
This paper considers the concept of interest and especially interest in science. An empirical study, which is based on theoretical considerations of the concept of interest and its relation to motivation and engagement, is described. The empirical study consists of life history interviews with six individuals, who all are engaged in nature and/or science as part of their job or hobby. The results from these interviews point to the need of a broader understanding of interest than is generally accepted in the traditional psychological sense. It is suggested that in terms of expressed interest, the notion of interest should be viewed partly as interest based on attitude and partly as interest based on action. The results also point to the need of clarifying the meaning of interest in science as it covers both interest in nature and being in nature, interest in science as a school subject, and interest in science itself.
\end{abstract}

\section{INTRODUKTION}

"Der er så meget andet $i$ verden end fysik!" Dette citat stammer fra en pige i 9. klasse, som egentlig havde meget gode evner inden for skolefaget fysik, men som alligevel syntes, at alle andre karrieremuligheder kunne være mere spændende end at fortsætte i en naturfaglig løbebane. Man kan forestille sig mange forklaringsmuligheder: Naturfagene fængede hende ikke, hun kunne ikke forestille sig at beskæftige sig med naturfaglige problemstillinger et helt arbejdsliv, hun fandt simpelthen ikke naturfagene interessante nok.

Samtidig tales der i disse år meget om den såkaldt vigende interesse for naturfagene både blandt forskere og politikere. Grunden til dette skal dels findes i problemer med at rekruttere et tilstrækkeligt antal studerende til de tekniske og naturvidenskabelige videregående uddannelser og dermed en mangel på kvalificeret arbejdskraft med naturvidenskabelig og teknisk baggrund og dels i en bekymring over tilstanden af den almene naturvidenskabelige dannelse hos børn og unge (se bl.a. Dansk Industri, 2001 og Andersen, Busch, Horst \& Troelsen, 2003). Inden for den seneste 10årige periode er der gennemført mange undersøgelser om unges interesse for naturfag, og næsten alle med forskellige definitioner af de involverede begreber: unge, interesse og naturfag (se Troelsen (2005) for en kort oversigt over hovedsageligt danske forskningsprojekter af denne art).

Men det er ikke kun et dansk fænomen - ej heller kun et nordisk - at der i disse år er fokus på interesse for naturfag. Også den store, internationale undersøgelse om 15-åriges holdninger til naturvidenskab og teknik, Relevance Of Science Education (ROSE), fra 2003 benytter sig bl.a. af interesse som en målestok for unges syn på naturfagene (Busch, 2005; Schreiner \& Sjøberg, 2005). 
Interesse som begreb bliver altså anvendt i vid udstrækning i større og mindre forskningsprojekter, som vil udsige noget om hvilken status naturfagene har blandt fx unge. En status, som kunne udmønte sig i om de unge finder skolefaget spændende, om de kan lide deres naturfagslærere og -timer, om de bruger tid på naturfaglige aktiviteter i deres fritid, fx ved at se fjernsynsudsendelser på "Animal Planet"-kanalen, lege med "Den lille kemiker" i kælderen eller gå til spejder, om de fremover vil studere naturvidenskabelige fag på en videregående uddannelse, osv. Men de færreste projekter er helt entydige i deres brug af begrebet - måske fordi interesse er en så naturlig del af hverdagssproget.

Derfor er sigtet med denne artikel at bidrage til en opklaring af, hvordan interessebegrebet kan forstås, når vi tænker på det som en parameter for noget andet - altså som en målestok og et udtryk for hvilket syn man har på et emne, i dette tilfælde naturfag. I den forbindelse er det vigtigt at klargøre, hvad denne artikel ikke er - den er ikke et forsøg på at definere interessebegrebet som sådan, men snarere at se på, hvordan interesse kan forstås og i særdeleshed hvordan interessebegrebet kan operationaliseres. Jeg vil i artiklen derfor først præsentere nogle teoretiske overvejelser om interessebegrebet, som fører til en analytisk model af interesse set i sammenhæng med begreberne motivation og engagement. Herefter introducerer jeg en empirisk undersøgelse, som har den udtrykte interesse for specielt naturfag som udgangspunkt. Undersøgelsen er baseret på livshistoriske interviews med seks personer, der beskæftiger sig med natur og/eller naturfagene enten i kraft af deres arbejde eller i deres fritid. Udsagnene fra disse interviews analyseres og diskuteres ud fra den analytiske model af interesse. Artiklen afsluttes med en perspektivering, som peger frem mod en mulig anvendelighed af resultaterne i forbindelse med fremtidig forskning om unges interesse for og valg af naturfag.

\section{TEORETISKE OVERVEJELSER OM INTERESSEBEGREBET}

Inden for den pædagogiske forskning er interessebegrebet et meget anvendt begreb. Ikke desto mindre anvender forskere interessebegrebet med forskellige betydninger, og der er generelt ikke enighed om, hvordan begrebet skal defineres (Gardner, 1998). Som en noget løs definition kan det dog siges, at interesse kan opfattes som en interaktion mellem et individ og dets omgivelser (Krapp, Hidi \& Renninger, 1992; Krapp, Renninger \& Hoffmann, 1998). Begrebet kan opdeles afhængig af indfaldsvinklen til denne interaktion i dels en individuel interesse, som tager udgangspunkt i individet, og dels en situationel interesse, som tager udgangspunkt i omgivelserne. Den individuelle interesse er et karaktertræk, en vedvarende tilstand, som er specifik over for bestemte objekter. Denne specificitet adskiller interessen fra andre beslægtede begreber, som fx nysgerrighed og opmærksomhed - man er således altid interesseret i noget. Den situationelle interesse omhandler elementer ved en given situation, som vækker individets interesse i en kortere eller længere periode, og kan derfor nærmere betragtes som en proces end en tilstand. Forskellen mellem den individuelle og den situationelle interesse kan således siges at være forskellen på "at være interesseret" og "at blive interesseret".

Her og nu vil jeg beskæftige mig nærmere med den individuelle interesse. Den pædagogisk-psykologiske forskning peger selv på, som nævnt ovenfor, at interessen altid har en indholdsmæssig specifik retning - at den er rettet mod noget bestemt (Krapp et al., 1992). Interesse bliver ligeledes beskrevet som en forudsætning for handling - hvad enten denne handling måtte forstås som tankevirksomhed eller en fysisk handling (Deci, 1992; Hidi \& Anderson, 1992; Renninger, 1992; Renninger, Hoffmann \& Krapp 1998). Derimod beskriver den pædagogisk-psykologiske forskning sjældent, at interessen har en handlingsmæssig specifik retning - at interessen også altid rettes mod noget på et bestemt måde. Du kan være interesseret på en måde, så du absolut må vide mere, du kan være interesseret på en måde, så du gerne vil have mere at vide, men ikke for alt i verden eller interesseret på en måde, så du synes det er meget underholdende i nuet, men ikke er noget du vil forfølge yderligere endsige huske på. Interessen kan med andre ord have forskelligt udtryk 
afhængig af hvilket engagement, du er villig til at investere i det emne, du finder interessant (Beyer, 1992). Engagement bliver dermed et vigtigt begreb i tilknytning til interesse-begrebet - faktisk ser de fleste forskere inden for feltet en sammenhæng mellem interesse og engagement med motivation som den medierende faktor (Deci, 1998; Schiefele, 1991;1998). Også van Aalst og kolleger (van Aalst, Kapteijn, Licht, Verbeek \& Emous, 1984) har foreslået, at interesse ses i tæt relation til motivation og engagement. Som det ses af figur 1, forstås interesse som en vedvarende, positiv holdning til et bestemt emne eller fagområde. Denne interesse kan også kaldes en generaliseret tilstand af nysgerrighed overfor noget. Den kan imidlertid følges op af motivation defineret som en intention om at engagere sig i den slags handlinger, som stemmer overens med interessen. Motivation på sin side hænger tæt sammen med engagement defineret som den handling, der tager højde for de faktorer ved situationen, som er afgørende for, om det er muligt at udføre den motiverede handling.

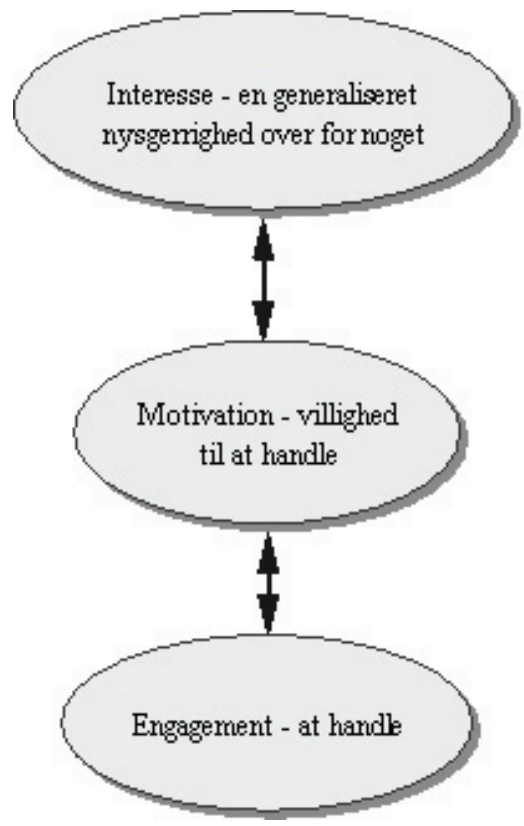

Figur 1: Skematisk oversigt over interessebegrebets definition og relation til motivation og engagement (Aalst et al., 1984).

Gardner (1985) påpeger, at der er mindst tre komponenter i interessebegrebet: grad af engagement (extent of commitment), fagrelationer (subject matter) og formål (purpose), og tager specielt van Aalst og kollegers (1984) tredeling mellem interesse, motivation og engagement op i sin beskrivelse af den første komponent. Den anden komponent om fagrelationer tager højde for, at der er forskel på interesse for de enkelte fagområder og sågar også forskel på interesse for enkelte elementer inden for et fagområde, når vi taler om naturfag som et samlet begreb. Den tredje komponent om formål refererer ifølge Gardner (1985) til at interesse for naturfag kan variere, alt efter hvilket formål elever har med at lære sig naturfag. Gardner (1985) foreslår altså, at ikke kun interessen for en given sag, men også overvejelser om genstanden for interessen, motivationen til at handle på interessen, graden og retningen af det engagement, som man er villig til at investere medtages, når man vil forsøge at få informationer om en persons interesse for eksempelvis naturfag.

Der er her tale om en væsentlig bredere definition af interessebegrebet end hvad man normalt i psykologisk forstand vil definere som interesse, men netop derfor også en mere dækkende definition, hvis sigtet er en udtrykt interesse. 
Indtil videre er altså begreberne interesse, motivation og engagement blevet introduceret, og jeg har argumenteret for, at de er tæt forbundne. Men også begrebet holdning (eng.: attitude) hører med til historien. Holdninger bliver som regel forbundet med individets følelser, værdier eller syn på et givent emne (Osborne, Simon \& Collins, 2003; Ramsden, 1998), men nogle forskere sidestiller ligefrem også holdninger med interesse (Evans, 1971; Gardner, 1975). Inden for holdningsforskningen har Potter og Wetherell (1987) påpeget, at en persons holdning til et givent emne bedst kan forstås, hvis holdningen ses i relation til den kontekst, hvori den kommer til udtryk. Således er der også inden for holdningsforskningen påpegninger af, at udtrykket af et givent begreb - det være sig holdning eller interesse - er en vigtig parameter i forståelsen af selve begrebet.

Mit fokus i denne artikel er derfor ikke at undersøge interessebegrebet i dets psykologiske forstand, men snarere at undersøge hvordan interesse kan udtrykkes - altså et forsøg på at operationalisere interessebegrebet. Heri ligger den egentlige udfordring for en klarlæggelse af interessebegrebet - hvordan kan det forstås og hvad vil det sige at være interesseret i noget? I det følgende vil jeg beskrive hvordan jeg med udgangspunkt i figur 1 har undersøgt interessebegrebet og særligt interesse for naturfag via narrative interviews.

\section{EMPIRISK UNDERS $\emptyset$ GELSE AF INTERESSE - METODE}

I forbindelse med undersøgelsen af interessebegrebet blev der gennemført en interviewundersøgelse. Undersøgelsen tog udgangspunkt i den udtrykte interesse, idet udvælgelsen af interviewpersoner skete på baggrund af de forskellige muligheder for at handle på en interesse. Der blev opstillet forskellige kategorier af arbejdsfunktioner, som indebar en interesse for naturfag:

- Man kan være interesseret i naturfag, så man vælger en videregående uddannelse og senere hen bliver forsker, fordi man gerne vil være med at skabe naturvidenskabelig viden selv.

- Man kan fascineres af naturvidenskaben for dens store spørgsmål om livets opståen, berettigelse og udøvelse og derved blive filosof med speciale i naturvidenskabelige spørgsmål.

- Man kan være interesseret i naturfag og gerne ville videregive sin interesse til andre. Man er ikke interesseret $\mathrm{i}$ at skabe ny viden, men ønsker at videregive allerede etableret viden og undren til andre og bliver dermed lærer eller anden formidler af naturfaglig viden.

- Man kan være særlig interesseret i naturvidenskaben som læren om naturen. Man er måske ikke så bogligt anlagt og udøver derfor sin interesse for naturen ved at være i naturen. Interessen for naturen manifesteres i fritidsaktiviteter, så som spejder, jæger, bjergbestiger eller amatørornitolog.

Jeg talte derfor med en naturvidenskabelig forsker (første kategori), en naturfilosof (anden kategori), en naturvejleder, en naturfaglig gymnasielærer, en studievært på et naturfagsformidlende tvprogram (alle tre fra tredje kategori) og en spejder (fjerde kategori). Interviewene er foregået som livshistoriske interviews (Goodson \& Sikes, 2001; Heyman \& Prieto, 1998; Horsdal, 1999) med særlig fokus på informanternes interesse for natur/naturfag. Begrundelserne for det livshistoriske interviewdesign skal ses med udgangspunkt $i$, at interviewpersonerne har engageret sig og dermed kan udsige noget om netop en udtrykt interesse.

Interviewene varede hver ca. 1 time og fandt sted enten i informantens hjem eller arbejdsplads. Interviewene blev optaget på en digital optager, transskriberet og analyseret i softwareprogrammet Atlas.ti.

Interviewdataene er analyseret vha. den teoretiske skematik om relationen mellem interesse, motivation og engagement - se fig. 1. I denne paradigmatiske tilgang til narrativ analyse (Potter, 1996) har jeg altså analyseret datamaterialet med fokus på hvornår og hvordan informanterne talte om deres værdier, holdninger eller nysgerrighed over for noget (interesse), hvornår og hvordan 
de talte om deres intentioner om eller villighed til at handle på deres interesse (motivation), og endelig hvornår og hvordan de talte om deres egentlige handlen på og engagement $\mathrm{i}$ interessen (engagement).

I analysearbejdet har det imidlertid vist sig, at dataene samtidig kan præsenteres som opdelt i tre temaer; 1) interesser i barndommen, 2) oplevelsen af skolen og skolefaget og 3) begrundelse for uddannelsesvalg. Begreberne interesse, motivation og engagement ækvivalerer imidlertid ikke 1:1 med disse tre temaer, selvom der er visse overlap. Således grundlægges ikke al interesse nødvendigvis i barndommen, ligesom al motivation til at føre interessen ud i livet heller ikke stammer fra mødet med fagene i skolen. Endelig er valg af uddannelse heller ikke den eneste måde at engagere sig i sin interesse på. Ikke desto mindre er de tre temaer opstået, fordi informanterne så at sige selv har talt om deres interesse og grupperet deres fortællinger inden for lignende rammer. For at være de livshistoriske data mest tro, er analysen altså struktureret efter disse tre analysetemaer (interesser i barndommen, oplevelsen af skolen og skolefag, og begrundelser for uddannelsesvalg) i det følgende. Først i diskussionsafsnittet vil jeg igen komme ind på analysens bidrag til den teoretiske tredeling mellem interesse, motivation og engagement (figur 1).

I alt blev som nævnt seks personer interviewet. I denne artikel præsenteres imidlertid kun tre af de seks informanters historier, dels af overskuelighedsgrunde og dels fordi disse tre i deres forskellighed repræsenterer det samlede materiale. Interviewpersonernes navne er i det følgende blevet ændrede og andre personlige kendetegn blevet anonymiserede.

De tre informanter er Peter, som er i starten af 50'erne og i dag arbejder i medieverdenen som professionel formidler af naturvidenskab for børn og unge, Jan, som er i starten af 30'erne og i dag arbejder i den økonomiske forvaltning i en kommune, og endelig Stina, som er i midten af 30'erne og i dag arbejder som medicinsk forsker.

\section{ANALYSETEMA 1: INTERESSER I BARNDOMMEN}

I mit oplæg til interviewene fortæller jeg informanterne, at jeg er interesseret i deres interesse, hvordan den er opstået og hvordan den har udviklet sig. Med et sådant udviklingshistorisk fokus er det kun naturligt, at de fleste informanter starter deres fortælling med erindringer fra barndommen. To af informanterne taler om deres interesse, som noget der er opstået i barndommen, som noget de "altid har været interesseret i". Denne opståen beskriver de som påvirket af deres forældre eller nære families holdninger og værdier, deres geografiske nærmiljø, eller deres kammeraters interesser. De to andre informanter oplever at deres interesse opstår i mødet med fagene i en skolemæssig kontekst.

\section{Peter - en bogdreng:}

Peter: Han [min far] formidlede til mig, fra jeg var ganske lille, [...] at naturvidenskabens verden var ligesom en parallel verden, ligesom et parnas. [...] Men jeg var i tvivl om, hvad jeg skulle vælge. Det betød, at jeg faktisk først valgte at studere biologi i 2. gymnasieklasse, samtidig med at jeg var nysproglig. Men jeg var som udgangspunkt en bogdreng og gik meget på biblioteket.

Peter er vokset op i byen og taler om sig selv som en bogdreng. Selvom hans far er automekaniker, der har efteruddannet sig til maskiningeniør, deler Peter i barndommen ikke sin fars interesse for teknik eller ingeniørkunst. I stedet lader han sig igen og igen indfange i de verdner, bøgerne præsenterer for ham, så han kan "falde $i$ staver over dem" og gå ind i det univers, som bøgerne åbner for ham. Han er meget videbegærlig og interesserer sig for noget af den simple grund, at det er nyt og ukendt for ham. 
Peters far ønsker, at hans søn vil interessere sig for naturvidenskab og med tiden tage den naturvidenskabelige uddannelse, som han aldrig selv fik, men først og fremmest ønsker han, at sønnen interesserer sig for noget. Peter ved godt, at faderen blot har ønsket, at hans børn skulle få et godt liv, men nævner senere i interviewet, at hans far har udøvet et ikke helt mildt pres på ham for at få ham til at indse storheden i naturvidenskaben og vælge et naturvidenskabeligt studium: "Min far forvaltede den cengstelse over hvordan det skulle gå hans børn, som et utålmodigt pres. Det var ikke hensigtsmoessigt, for $i$ stedet skabte det forvirring og støj, fordi man strittede $i$ alle mulige retninger og måske endda imod i protest." Så selvom Peter har kunnet mærke, at faderen har tilbudt ham endnu et univers - nemlig det naturvidenskabelige - at gå ind i, så har han - på grund af faderens facon og "utålmodige pres" - ikke kunnet finde vejen derind og "måske endda i protest" ikke villet finde en vej derind.

\section{Jan - spejder ved et tilfælde}

I: Kan du fortælle om, hvorfor du begyndte som spejder?

Jan: Det var en irritation over at en af mine klassekammerater ikke kunne lege! Det var fordi, han gik til noget mandag eftermiddag, men jeg kunne da prøve at gå med. Og så startede vi sammen [...], men jeg blev hængende. Fordi jeg syntes godt om aktiviteterne og de rammer, som aktiviteterne foregik i. Og også fordi det handlede om at tage ud i naturen.

Jan er vokset op i et "kedeligt rakkehuskvarter", men flytter med sin mor til en anden by, hvor det er mere oplagt at gøre brug af naturen som legeplads, da han er 10 år. Skiftet i bosted betyder, at Jan får kontakt til nye venner med nye fritidsinteresser, interesser, som han "ikke vidste man kunne have". Disse venner introducerer ham både til spejder-interessen og til sejler-interessen. På et tidspunkt føler Jan, at han må prioritere mellem disse to interesser, da han ikke har tid og energi til at engagere sig i den grad han ønsker det i begge interesser. Han vælger spejderarbejdet, fordi han godt kan lide de aktiviteter, der er forbundet med det, og fordi han godt kan lide at være i naturen. Hans fornøjelse ved at være i naturen er ikke noget, som i speciel grad er påvirket af hans forældre. Som barn var familien af og til på telttur i deres sommerferier, men ikke som en fast tilbagevendende begivenhed, og når familien ellers var på ferie, nød Jan specielt gåturene i det fri. Jans fascination ved spejderlivet gælder først og fremmest muligheden for at være ude i den friske luft: "Det er bare det at voere ude, som jeg godt kan lide. Mere prcecist kan jeg ikke komme det. Det har ikke gjort at jeg har dygtiggjort mig inden for naturområdet, dvs. jeg kan kende et bøgetrae, men jeg skal slå op i en bog, hvis det bliver bare en smule mere avanceret. Så det jeg er bedst til, det er at undres." Jan går ikke til spejder, fordi han ønsker at lære noget om planter og dyr, men mere fordi han er fascineret af, hvad man kan bruge naturen til og hvilke aktiviteter, naturen kan bidrage med rammer til. Han er bedst til at undres over naturen, men han er ikke interesseret $\mathrm{i}$ at følge denne undren op, at tage konsekvensen af denne undren ved fx at sætte sig ind i nogle biologiske sammenhænge.

\section{Stina - nysgerrig og ambitiøs}

Stina: [Jeg har] altid været meget fascineret af hjernen. Hvorfor man gjorde, som man gjorde, og hvordan det kunne være, at folk tænkte som de gjorde, og hvorfor de blev sure, og hvorfor de blev forelskede, hvorfor man reagerede forskelligt i forskellige situationer. Og hele tiden reflekterede jeg over, at det var fordi hjernen fungerede på en speciel måde, at man reagerede sådan. Så derfor har jeg egentlig i meget lang tid gerne villet være hjerneforsker - uden egentlig at vide, hvad det gik ud på...

Stina er meget målrettet og ambitiøs. Hun har i en tidlig alder besluttet sig for at blive hjerneforsker på baggrund af en fascination af den menneskelige hjerne. En fascination, som hun ikke helt ved, hvor kommer fra. Hendes morfar husker hun ikke alene som matematisk begavet men også som matematisk interesseret, og hun mener at være blevet inspireret af hans interesse. Som fritidsfornøjelse har hun nemlig altid løst matematiske opgaver og gåder sammen med sin morfar og sin 
mor. Begge hendes forældre er uddannede folkeskolelærere i humanistiske fag, men moderen har efterfølgende videreuddannet sig til matematiklærer.

Stinas ambitiøse natur kommer også til udtryk i hendes andre barndoms- og ungdomsinteresser. Hun har udover at være interesseret i hjernen og i at løse matematiske opgaver, dyrket atletik, spillet beachvolleyball og tværfløjte - alt sammen på eliteniveau. Hun betegner sig selv som "et konkurrencemenneske $i$ alle henseender", og viser med hendes øvrige livshistorie ligeledes, at hun for alt i verden ønsker at gennemføre de ting, hun sætter sig for at gennemføre, og i langt de fleste tilfælde også får sit ønske opfyldt.

\section{AnAlysetema 2: OpleVelsen AF SKOlen og SKOlefagene}

Skolen spiller en central rolle for informanterne. Nogle oplever, at deres interesse først rigtigt bliver antændt i skolen, andre at skolen er eksponent for en helt anden - og forkert - vinkel på deres interesse. Når talen falder på skolen er alle tre informanter imidlertid enige om at sidestille deres oplevelser af skolefagene med deres oplevelser af læreren. Oplevelsen af skolefagene samtænkes ikke med undervisningslokaler, eksamener eller undervisningsmaterialer og kun i enkelte og sekundære tilfælde med fagenes egenart som fag. Dermed er det ikke sagt, at der hos informanterne kan spores en sammenhæng mellem lærerens måde at undervise på og elevernes interesse i et givent fag. Selv de informanter, som tydeligst kan pege på en inspirerende lærer som hoveddrivkraften i udmøntningen af deres interesse, anerkender, at denne lærer har virket inspirerende på dem, men bestemt ikke, nærmest tværtimod, på andre.

\section{Den inspirerende lærer}

Peter: Så fik vi en biologilærer, og jeg tror det var hans skyld. Jeg var sproglig [dvs. studerende på de sproglige gymnasielinje, RPT], så jeg vidste ikke, at jeg var interesseret. [...] Han åbnede i sin undervisning et parallelt univers for mig. [... Min lærer] var med på noderne, og han havde kontakt til én, som havde været elev på vores skole, som arbejdede i Cambridge, hvor Watson og Crick var. Han formidlede den kontakt til os, og vi fornemmede, at han havde kontakt til, hvor der skete noget erkendelse, som var dybt og som handlede om livet. Det fascinerede os. Og derfor ville jeg læse biologi.

Peter vælger den nysproglige linje i gymnasiet, fordi han på det tidspunkt er overbevist om, at han skal læse japansk. Han kommer imidlertid i kontakt med en biologilærer, som får ham til at skifte kurs. Denne biologilærer er, i modsætning til Peters egen far, i stand til at åbne døren ind til det naturvidenskabelige univers ved at belønne Peters interesse med informationer. Og informationer, hvad enten det findes i bogform eller i form af en vidende lærer, er i høj kurs hos Peter. Men mens denne lærer har haft en afgørende indflydelse på Peters interesse for biologi, så er han godt klar over, at ikke alle hans klassekammerater har fundet læreren inspirerende, endsige god. "Min biologilcerer var sådan én, der holdt hof", siger han og indikerer dermed at de, som "kunne komme ind $i$ varmen, sådan var voerdige til det" fik en god oplevelse, mens de, som ikke kunne mobilisere en interesse for biologi eller biologiske informationer blev efterladt ude i kulden og kunne for så vidt lige så godt have været fraværende i biologitimerne - læreren ville have været ligeglad.

Biologien opfylder to ønsker hos Peter, ikke alene er det et nyt univers, han kan træde ind i og hvis udstrakthed han kan lade sig fascinere af, men indholdet i dette univers opfylder ligeledes hans behov for forklaringer. Hans lærer har selv skrevet en doktorafhandling (som Peter selvfølgelig også læser) og har ydermere kontakt til nogle forskere, som arbejder med banebrydende forskning, "som var dybt og som handlede om livet." Peter oplever, at biologien, personificeret ved biologilæreren, kan give ham svar på, hvor hans plads i livet er. Som han selv siger, er han "altså blevet interesseret i biologi gennem loerere." 


\section{“Det var en undervisningssituation. Og så var det noget helt andet."}

Jan: [Biologi i skolen] sagde mig faktisk ikke ret meget. [...] Det handlede meget om at tage ud i en å, hælde noget op i et glas og kigge på det i et forstørrelsesapparat.

I: Men I var dog trods alt ude ved åen. Kunne du ikke drage nogen paralleller mellem dit spejderarbejde og dét?

J: Nej, for det var en undervisningssituation. Og så var det noget helt andet. Jeg tænkte over, at skolen var ét og spejder noget andet. [...] Formålet med undervisningen var at finde ud af noget om naturen og miljøet. [...] Men i spejderlivet handlede det mere om at fare rundt og lege i naturen. [...] Naturen er bare en ramme for mig, mens aktiviteterne har været i fokus.

På trods af, at Jan har stor lyst til og interesse i at være i naturen i kraft af sine fritidsaktiviteter i spejdertroppen og i sejlklubben, så bliver denne interesse ikke uddybet eller næret ved naturfagsundervisningen i skolen. Jan oplever først og fremmest biologiundervisningen som undervisning, og så er "det noget helt andet". Hvis Jan bliver underlagt - mere eller mindre udtalte - krav om, at han skal lære og forstå noget i forbindelse med hans oplevelser i naturen, så interesserer de ham ikke længere. Naturen er til at være i, ikke til at lære om: "Jeg synes det var så meget undervisningsrettet, at det tog fokus voek fra naturoplevelsen."

\section{Interesse på trods af skolen}

Stina: Joh, kemi syntes jeg også var spændende. Det er igen nysgerrigheden; dét med at man kan blande noget sammen, og så sker der noget nyt. Jeg var faktisk ikke særlig god til kemi, jeg var meget bedre til alt muligt andet. Men det var spændende, ja jeg syntes det var fantastisk og utroligt interessant, men jeg fik min dårligste karakter i kemi, alligevel havde jeg det på højt niveau [i gymnasiet].

I: Hvorfor valgte du det så på højt niveau?

S: Fordi det var sjovt!

I: I forhold til fx fysik?

S: Nej, fysik var jeg også helt vild med, det er jeg også rigtig god til, faktisk. [...] Nej, fysik kunne jeg bestemt også godt lide.

Når Stina taler om sin interesses opståen, nævner hun ikke automatisk skolen. Hun synes selv, at hendes folkeskoletid har været fagligt utilstrækkelig, idet hendes matematiklærer havde personlige problemer, som desværre øjensynligt påvirkede ham i hans virke som folkeskolelærer. Skolens ledelse gjorde ifølge Stina ikke noget ved problemet, så Stina fik hurtigt funktion af hjælpelærer i matematiktimerne dels i kraft af hendes egne interesser og evner inden for matematik og dels fordi hendes mor - som havde efteruddannet sig til matematiklærer - kunne og ville hjælpe hende. Stinas interesse brænder altså igennem de dårlige oplevelser i folkeskolen, og man kan sige, at hun vedbliver at være interesseret i matematik og naturfag til trods for undervisningen i folkeskolen. At Stina mere eller mindre bevidst går ind i hjælpelærerfunktionen virker måske i virkeligheden ansporende på hendes interesse. I gymnasiet kan hun nemlig stadig lide fagene - hun synes, at de er sjove og spændende. Hun vælger kemi på højt niveau, men ville egentlig hellere have haft fysik. Det kan imidlertid ikke lade sig gøre pga. nogle bindinger, som der på det tidspunkt er imellem valgfagene i gymnasiet. Stina begrunder sine interesser for gymnasiefagene med, at de først og fremmest er spændende og pirrer hendes nysgerrighed. Lærerne i fagene er i den forbindelse betydningsfulde, idet Stina senere beskriver dem som fascinerende i kraft af deres engagement. Lærerne har imidlertid også en anden slags - negativ - betydning. Stina fortæller senere i interviewet om, at hun måske netop ikke vælger fysik, fordi hun ikke ville risikere at skuffe sin lærer, som opfatter hendes evner inden for fysik som meget større end hun selv gør. Hun har fået gode karakterer i både fysik og kemi, men føler ikke selv at hun kan leve op til de forventninger, som lærerne implicit stiller til hende som en naturlig konsekvens af hendes gode karakterer. Det er svært for perfektionisten Stina at slå sig til tåls med bare at være middelgod. 


\section{ANALYSETEMA 3: BEGRUNDELSER FOR UDDAN NELSESVALG}

Informanterne i denne undersøgelse har alle tre foretaget et uddannelsesvalg - nogle endda flere i kraft af efter- og videreuddannelse. Udvælgelsen af informanter er som nævnt sket primært ud fra hvilket uddannelsesvalg disse personer har foretaget, nemlig inden for det naturfaglige område. Derfor taler de naturligvis alle om den - i de fleste tilfælde - positive relation mellem deres naturfaglige interesse og deres valg af naturfaglig uddannelse. At interesse er bestemmende for hvilken uddannelsesretning man vælger er godtgjort og beskrevet i mange andre undersøgelser (Broch \& Egelund, 2001; Egelund \& Hulvei, 2002; Jensen, Mogensen \& Holm, 1997; Skov, 1998; Troelsen, 2005), men heller ikke disse undersøgelser giver noget udtømmende svar på hvordan interesse er bestemmende for uddannelsesvalget. Dertil mangler vi nogle oplysninger fra personer som har tilsvarende naturfaglige interesser men ikke har valgt naturfaglige uddannelsesretninger. Derimod giver undersøgelsen her et foreløbigt billede af interesse, som en bestemmende faktor for retningen af uddannelsesvalget, men ikke som den eneste faktor. Der er stadig en række ydre rammebetingelser af forskellig art, som fx studiemiljø, familiemæssige traditioner og rollemodeller (eller manglen på samme), som også kan have en vis indvirkning på uddannelsesvalget.

I det følgende er analysen ikke delt op i de tre personers egne historier som i de to foregående analysetemaer, men samlet dels for at tydeliggøre forskelle og ligheder mellem deres begrundelser og dels fordi interviewpersonerne ikke har beskrevet deres begrundelser for uddannelsesvalget i nær så tætte detaljer som de foregående temaer.

De tre informanters endelig uddannelsesvalg bliver fx påvirket af forskellige faktorer, både hvad angår art og tidsmæssig indvirkning. Peter bliver påvirket af karismatiske biologilærere i både gymnasiet og på de suppleringskurser, som han efterfølgende deltager i og vælger herefter at læse biologi på universitetet. Stina er til trods for hendes tidlige drøm om at blive hjerneforsker efter gymnasietiden kun sikker på, at hun skal læse et naturvidenskabeligt fag. Hun besøger naturvidenskabelige fagmiljøer på forskellige uddannelsesinstitutioner, men bliver overbevist om at ville læse medicin på universitetet, da hun sammen med en veninde oplever det gode studiemiljø og "de lcekre fyre" på medicinstudiet. Derimod vælger Jan uddannelser med naturvidenskabeligt indhold fra allerede i gymnasiet:

I: Hvad ville du være i gymnasiet?

Jan: I starten ville jeg stadig være civilingeniør, men så fandt jeg ud af, hvor meget fysik og kemi der skulle til. Da jeg så prøvede det og fandt ud af hvor god jeg var til det, gik det op for mig at jeg ikke ville blive en særlig god ingeniør. Så tog jeg en samfundsfaglig linje i stedet, og fandt ud af at det mere var mig, og så gik jeg videre ud af det spor. Jeg startede på den matematisk linje med fysik, men skiftede så over til den samfundsfaglige linje.

Jan vælger at læse økonomi på universitetet, men fortsætter sit spejderarbejde i fritiden. Hans engagement i spejderarbejdet skifter dog mere og mere fokus til den ledelsesmæssige og organisatoriske del og væk fra de konkrete naturoplevelser og aktiviteter i naturen.

I deres italesættelse af og begrundelse for uddannelsesvalg og valg af livsbane i det hele taget, er det gennemgående tema "tilfældigheder". De tre informanter fortæller, at tilfældighederne har styret dem i deres valg, men ikke sådan at forstå, at det er tilfældigt, hvad de har valgt. Deres interesse(r) har styret dem i en særlig retning og inden for denne retning har pludseligt opståede muligheder, tilfældige møder med andre mennesker eller oplevelsen af en skelsættende begivenhed påvirket deres endelige valg af uddannelse. Så når Stina siger om hendes valg af medicinstudiet: "Og derfor er jeg vanvittig glad for at have valgt medicinstudiet. Og det var måske lidt en tilfceldighed $i$ starten.", så er det måske tilfældigt at det netop blev medicinfaget og ikke ingeniørfaget hun valgte at engagere sig i, men det var bestemt ikke tilfældigt, at det blev et fag inden for den naturvidenskabelige fagkreds. På den måde styrer interessen informanternes uddannelsesvalg som en vifte af muligheder, hvorimellem tilfældigheder og aktuelle begivenheder kan bestemme det endelige valg. 


\section{DISKUSSION: HVAD KAN VI LAERE OM INTERESSEBEGREBET OG INTERESSE FOR NATURFAG UD FRA DET EMPIRISKE MATERIALE?}

Men selvom de tre informanters interesser er styrende for deres uddannelsesvalg, og selvom de alle tre interesserer sig for natur eller naturfag, så ender de ikke i den samme uddannelse. De engagerer sig forskelligt.

Deres vej mod uddannelsesvalget er heller ikke ens. De motiveres forskelligt. Peter interesserer sig for naturvidenskabelige - boglige - emner fra barnsben, men bliver nærmest demotiveret af sin far og dennes uudtalte og udtalte forventninger om, at Peter skal blive naturvidenskabsmand eller ingeniør. Først da han kommer i gymnasiet og møder en speciel lærer, motiveres han igen og engagerer sig i en lang videregående uddannelse som biolog. Jan interesserer sig for natur og naturoplevelser som barn, men bliver demotiveret i skolen, hvor alting skal forstås og forklares og ikke bare opleves. Han engagerer sig ikke i naturfagsundervisningen, men vælger at engagerer sig i skolefagsudgaven af en anden af sine interesser, nemlig økonomi. Hans naturinteresse vælger han at udleve i sin fritid som spejder. Stina er interesseret i matematik og opgaveløsning som barn, og denne interesse vedbliver hun at have op gennem folkeskoletiden til trods for, at skolen gør alt, hvad den kan for at demotivere hende. I gymnasiet engagerer hun sig i naturfagstimerne og synes (endda), at de er sjove. Hun engagerer sig så meget i sin interesse, at hun vælger at læse en lang videregående uddannelse inden for sundhedsvidenskab.

Ser vi disse beretninger fra informanterne i relation til den teoretiske skematik (figur 1), ser vi, at interesse kan påvirkes og udmøntes på forskellig vis. Så det at være interesseret i et givent emne eller område, kan dække over en lang række muligheder for engagement og motivationsfaktorer. Hvis alle informanters beskrivelse af deres interesse skal indeholdes i det samme interessebegreb, må vi faktisk tænke på motivation og engagement ikke alene som begreber, der relaterer sig til interesse, men som faktorer $i$ en interesse, ganske som Gardner (1985) også foreslår. En sådan inkorporering af motivationsfaktorer og engagement $i$ interessebegrebet kan gøres ved at skelne mellem en holdningsbaseret interesse og en handlingsbaseret interesse. Holdningsbaseret interesse skal her forstås som en persons værdier og (positive) holdninger til et givent emne, og begreberne holdning og interesse kommer derved til at relatere til hinanden på en måde, så interesse kan siges at være den positive holdning overfor et givent emne. Dette falder i tråd med Gardner (1975), som sidestiller holdninger til naturfag med interesse for naturfag. Tilkendegiver man en holdningsbaseret interesse over for noget, betyder det at man har en positiv holdning til dette, synes det lyder spændende, er nysgerrighed over for det, og at det repræsenterer nogle af de livsværdier, man i øvrigt har. Men at have en holdningsbaseret interesse for noget siger ikke noget om, hvordan og hvorvidt man har tænkt sig at udmønte denne interesse. Det er så at sige en ren meningstilkendegivelse om et givent emne uden krav om, at denne meningstilkendegivelse skal resultere i nogen form for handling - hverken mentalt eller fysisk. Som Potter og Wetherell (1987) påpeger, så kan motivationen til at agere anderledes, end hvad der var forventet ud fra en given holdning, fx være stærkere. Den handlingsbaserede interesse dækker derimod over både en holdningsbaseret interesse, motivation og engagement, som illustreret i figur 2.

Ved at definere den handlingsbaserede interesse som indeholdende disse tre dimensioner (holdningsbaseret interesse, motivation og engagement) anerkendes netop, at interessens art er afhængig af interessens udtryk - at man kan være interesseret på forskellige niveauer. På sigt kan denne beskrivelse af interesse medvirke til en mere præcis operationalisering af begrebet, når fx elever $\mathrm{i}$ store, internationale spørgeskemaundersøgelser spørges om deres interesse for at lære om bestemte emner i skolens naturfaglige undervisning. Man kunne forestille sig, at spørgeskemaspørgsmål blev formuleret som: "Ville du synes, at det var interessant at studere dette emne i en videregående uddannelse?" eller som: "Ville du synes, at det var interessant at se en tv-udsendelse om dette emne?", alt efter hvilken grad af engagement forskeren fandt passende i forhold til at kunne på- 


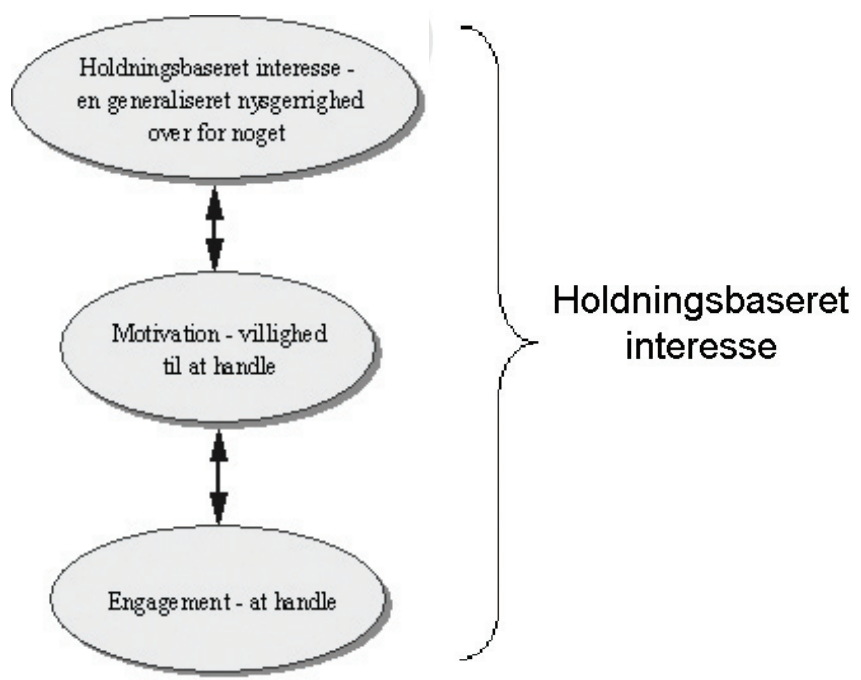

Figur 2: Model over den handlingsbaserede interesse, som indeholdende holdningsbaseret interesse, motivation og engagement.

beråbe sig at have interesse i et bestemt emne. Med andre ord vil det i fremtiden være nødvendigt med en præcisering af hvilket engagement, man ønsker interessen skal give sig til udtryk som, for at kunne leve op til den definition af interesse, som aktuelt er i brug i en given undersøgelse.

Samtidig har analyseresultaterne et blindt punkt i forhold til modellen i figur 2: de udsiger ikke noget om muligheden for et ikke-engagement. I kraft af udvælgelsesproceduren af interviewpersoner, hvor personer blev valgt ud, som allerede havde engageret sig, er de personer ikke kommet til orde, som har en naturfagsinteresse og -motivation, men som ikke har engageret sig. De empiriske data og analyser giver altså ikke noget svar på, hvorfor nogle personer vælger ikke at handle på deres holdningsbaserede naturfagsinteresse. Har der været andre interesser, som har været stærkere? Er de blevet demotiverede til at engagere sig? Er der ingen (passende) rollemodeller, som kan give de interesserede inspiration til engagement? Analyseresultaterne kan ikke svare på disse spørgsmål, og kan derfor heller ikke verificere den teoretiske model - hverken i retning af at holdningsbaseret interesse altid følges op af motivation og derefter engagement, eller i retning af engagement altid skyldes motivation og forud for dette, holdningsbaseret interesse. De peger alene i retning af, at engagement og handlen er en vigtig del af forståelsen af interessebegrebet - især i en operationalisering af interesse, som er nødvendig, hvis vi fremover skal kunne anvende begrebet som målestok for hvilken status naturfagene har hos eksempelvis unge, som står over for at skulle vælge uddannelse og dermed engagere sig på en bestemt måde i naturfagene. Osborne og kolleger (2003) er lidt inde på dette behov for præcisering af interessens handlingsrettethed, når de plæderer for, at man i stedet for kvantitativt at måle elevers generelle holdninger til naturvidenskab snarere kvalitativt skulle undersøge elevernes holdninger til naturfag som skolefag og deres holdninger til at studere naturfag i deres fremtidige skole-/uddannelsesliv.

Interviewpersonernes udmøntning af deres naturfagsinteresse har altså været forskellig. Deres holdningsbaserede interesse kan imidlertid også tolkes som værende forskellige. Jan elsker at være og lege i naturen, og mister interessen, så snart han skal forstå og ikke opleve den natur, han færdes i. Stina elsker at løse opgaver og "regne den ud", og fascineres af naturfagene i skolen - ikke med hjælp fra en lærer, men af fagene i sig selv. Peter elsker at læse og lære nyt og er meget optaget af naturvidenskaben som forklaringsmodel på eksistentielle problemstillinger. De tre interesser har 
forskellige genstandsfelter, som groft sagt kan deles op som interesse for natur og naturoplevelser, interesse for naturfag som skolefag, og interesse for naturvidenskaben som forskningsområde. Interesse for natur og naturoplevelser sammenfatter interesse for at være i naturen, at bruge naturen som et rum for rekreation og pladskrævende aktiviteter. Den handler også om at se naturen som et middel til at opnå en praktisk erfaring med naturfagene. Interesse for naturfagene som skolefag dækker som nævnt over interesse for at kunne "regne den ud", at kunne løse nogle opgaver, som er blevet dig stillet - groft sagt at lykkes som elev. Interesse for naturvidenskaben som forskningsområde handler om at være fascineret af videnskaben i sig selv, at være interesseret i de uløste mysterier, som videnskaben endnu ikke har kunnet svare på. Fascinationskraften ligger her også hos naturvidenskaben som en universel forklaringsmodel.

Det har imidlertid ikke været hensigten med interviewundersøgelsen at undersøge genstandsfeltet for naturfagsinteresse nærmere, så derfor er disse resultater af analysen i sagens natur kun tentative, men naturligvis relevante at arbejde videre med.

\section{KONKLUSION OG PERSPEKTIVERING - HVAD ER SÅ INTERESSE OG INTERESSE FOR NATUR- FAG?}

Hvad er så interesse? Denne artikels pointe er, at interesse kan være mange forskellige ting, idet man kan være interesseret på mange forskellige måder.

Ved at adskille en handlingsbaseret interesse fra en holdningsbaseret interesse, så den holdningsbaserede interesse sammen med motivation og engagement udgør grundstenene i en handlingsbaseret interesse, tages det alvorligt, at interessens art er afhængig af interessens udtryk - og dermed at man kan være interesseret på forskellige måder. Præcisering af netop denne egenskab hos interessebegrebet er nødvendig i fremtidige undersøgelser af den omtalte stadig vigende interesse for naturfagene blandt børn og unge. En præcisering af, hvordan en given interesse for et naturfagligt emne skal komme til udtryk, kan give et mere nuanceret billede af unges interesse for naturfag.

En anden nødvendig præcisering, som resultaterne præsenteret i denne artikel peger på, er præciseringen af interessens genstandsfelt. Når vi igen taler om den svigtende interesse for naturfag blandt unge, er det ikke altid tydeligt, om vi taler om interessen for natur og naturoplevelser, interessen for skolens naturfag eller om interessen for naturvidenskaben. Det kunne meget vel være, at der ikke var samme vigende tendens for alle disse tre slags "naturfagsinteresser" blandt de unge. Det kunne tænkes at de unge måske nok var meget interesserede i en væren i naturen, men ikke i den teoretiserende omgang med naturvidenskaben. Det kunne også godt tænkes, at de unge var meget interesserede i naturvidenskaben som en universel forklaringsmodel og med dens fokus på verdens endnu uløste mysterier, som den fx blev præsenteret for dem i populærvidenskabelige tidsskrifter og fjernsynsprogrammer, men bestemt ikke i den form for naturfag, som blev præsenteret for dem i en skolesammenhæng. I relation til dette behov for præcisering er undersøgelserne og resultaterne, som er beskrevet i denne artikel, første del af et større projekt. Resultaterne skal derfor ses som dels resultater i sig selv og dels som udgangspunkter for en fremtidig undersøgelse. Helt konkret peger resultaterne frem imod undersøgelser blandt unge (fortrinsvis 17-18-årige) om deres interesse for natur/naturfag/naturvidenskab. Specielt skal det blive interessant at undersøge, hvordan de unges interesse for skolens naturfag (eller manglen på samme) fx er farvet af deres interesse for hhv. natur og naturvidenskab. Et resultat af en sådan undersøgelse kunne give anledning til overvejelser om en naturfagsundervisning, som bevidst - og eksplicit - fokuserede på begge disse tilgange til naturfagsinteresse i bestræbelserne på at overbevise flere unge om at vælge naturfaglige uddannelser som en relevant og attraktiv karrierevej. 


\section{REFERENCER}

Andersen, N. O., Busch, H., Horst, S., \& Troelsen, R. (2003). Fremtidens naturfaglige uddannelser. Naturfag for alle - vision og oploeg til strategi. København: Undervisningsministeriet.

Beyer, K. (1992). Det er ikke tænkning det hele. I: H. Nielsen \& A. Paulsen (red.), Undervisning $i$ fysik - den konstruktivistiske idé (s. 117-140). København: Gyldendal.

Broch, T., \& Egelund, N. (2001). Elevers interesse for naturfag og teknik. Et elevperspektiv på undervisningen. København: Danmarks Pædagogiske Universitet.

Busch, H. (2005). Ungdomskulturen: Elevernes erfaringer, holdninger og interesser. I: S. Sjøberg (red.), Naturfag som almendannelse - en kritisk fagdidaktik. Århus: Klim.

Dansk Industri. (2001). Undersøgelse af indsats for at fremme interessen for natur og teknik fagene: Danmark i et internationalt perspektiv. København.

Deci, E. L. (1992). The relation of interest to the motivation of behavior. I: K. A. Renninger, S. Hidi,. \& A. Krapp (red.), The role of interest in learning and development (s. 43-70). Hillsdale: Lawrence Erlbaum Associates.

Deci, E. L. (1998). The relation of interest to motivation and human needs - the self-determination theory viewpoint. I: L. Hoffmann, A. Krapp, K. A. Renninger \& J. Baumert (red.), Interest and learning (s. 146-162). Kiel: IPN.

Egelund, N., \& Hulvei, P. (2002). Folkeskoleelevers holdninger til naturfag og teknik. En kvantitativ undersøgelse omfattende 1050 elever. København: Danmarks Pædagogiske Universitet.

Evans, K. M. (1971). Attitudes and interests in education (2 ed.). London: Routledge \& Kegan.

Gardner, P. L. (1975). Attitudes to science: A review. Studies in Science Education, 2, 1-41.

Gardner, P. L. (1985). Students' interest in science and technology: An international overview. I: M. Lehrke, L. Hoffmann \& P. L. Gardner (red.), Interests in science and technology education. Kiel: IPN.

Gardner, P. L. (1998). The development in males' and females' interest in science and technology. I: L. Hoffmann, A. Krapp, K. A. Renninger \& J. Baumert (red.), Interest and learning (s. 4157). Kiel: IPN.

Goodson, I., \& Sikes, P. (2001). Life history research in educational settings: Learning from lives. Buckingham: Open University Press.

Heyman, I., \& Prieto, H. P. (red.). (1998). Om berättelser som redskap i pedagogisk forskning (Vol. 131). Uppsala: Uppsala Universitet.

Hidi, S., \& Anderson, V. (1992). Situational interest and its impact on reading and expository writing. I: K. A. Renninger, S. Hidi, and A. Krapp (red.), The role of interest in learning and development (s. 215-238). Hillsdale: Lawrence Erlbaum Associates.

Horsdal, M. (1999). Livets fortoellinger: Valby: Borgens Forlag.

Jensen, T. P., Mogensen, K. B., \& Holm, A. (1997). Valg og veje i ungdomsuddannelserne. København: AKF Forlaget.

Krapp, A., Hidi, S., \& Renninger, K. A. (1992). Interest, learning and development. I: K. A. Renninger, Hidi, S. and Krapp, A. (red.), The role of interest in learning and development (s. 3-26). Hillsdale: Lawrence Erlbaum Associates.

Krapp, A., Renninger, K. A., \& Hoffmann, L. (1998). Some thoughts about the development of a unifying framework for the study of individual interest. I: L. Hoffmann, A. Krapp, K. A. Renninger \& J. Baumert (red.), Interest and learning (s. 455-468). Kiel: IPN.

Osborne, J., Simon, S., \& Collins, S. (2003). Attitudes towards science: A review of the literature and its implications. International Journal of Science Education, 25(9), 1049-1079.

Potter, J., \& Wetherell, M. (1987). Discourse and social psychology: Beyond attitudes and behaviour. London: Sage Publications.

Potter, W. J. (1996). An analysis of thinking and research about qualitative methods. Mahwah: Lawrence Erlbaum.

Ramsden, J. M. (1998). Mission impossible? Can anything be done about attitudes to science? 
International Journal of Science Education, 20(2), 125-137.

Renninger, K. A. (1992). Individual interest and development: implications for theory and practice. I: K. A. Renninger, Hidi, S. and Krapp, A. (red.), The role of interest in learning and development (s. 361-396). Hillsdale: Lawrence Erlbaum Associates.

Renninger, K. A., Hoffmann, L., \& Krapp, A. (1998). Interest and gender: Issues of development and learning. I: L. Hoffmann, A. Krapp, K. A. Renninger \& J. Baumert (red.), Interest and learning (s. 9-21). Kiel: IPN.

Schiefele, U. (1991). Interest, learning, and motivation. Educational Psychologist, 26(3\&4), 299323.

Schiefele, U. (1998). Individual interest and learning - what we know and what we don't know. I: L. Hoffmann, A. Krapp, K. A. Renninger \& J. Baumert (red.), Interest and learning (s. 91104). Kiel: IPN.

Schreiner, C., \& Sjøberg, S. (2005). Et meningsfullt naturfag for dagens ungdom? Nordina, 2, 1835.,

Skov, P. (1998). Unges fremtid - meget afgøres tidligt. Erfaringer fra en forløbsundersøgelse. København: Danmarks Pædagogiske Institut.

Troelsen, R. (2005). Unges interesse for naturfag - hvad ved vi og hvad kan vi bruge det til? MONA. Matematik- og Naturfagsdidaktik - tidsskrift for undervisere, formidlere og forskere, 2, 7-21.

van Aalst, H. F., Kapteijn, M., Licht, P., Verbeek, G., \& Emous, R. (1984). National studies: Interests in science and technology education: The Netherlands, 12th IPN Symposium. University of Kiel, Germany. 